\title{
Winter grazing of forages - soil moisture and tillage methods impact nitrous oxide emissions and dry matter production
}

\author{
S.M. THOMAS, G.S. FRANCIS, H.E. BARLOW, M.H. BEARE, L.A. TRIMMER, \\ R.N. GILLESPIE and F.J. TABLEY \\ Crop \& Food Research, PB 4704, Christchurch \\ thomass@crop.cri.nz
}

\begin{abstract}
Grazing of winter forage crops can cause extensive compaction of soils that may reduce re-growth of crops and lead to large emissions of nitrous oxide $\left(\mathrm{N}_{2} \mathrm{O}\right)$. A field trial was undertaken to investigate the effects of cattle grazing at three soil moisture contents on $\mathrm{N}_{2} \mathrm{O}$ emissions and dry matter (DM) production of a winter forage crop established by intensive (IT), minimum (MT), or no tillage (NT) practices. A multi-grazing triticale (cv. Doubletake) was sown in the main tillage plots in March 2003. In June, the tillage plots (three replicates) were each divided into six split plots and additional treatments were imposed: simulated treading $(+/-)$; soil moisture at treading ( $<$ field capacity $(\mathrm{FC}) ; \mathrm{FC}$; and $>\mathrm{FC}$ ); and urine (+/-). Tillage practice and soil moisture content at treading affected soil compaction. The greatest increase in surface soil $(0-7.5 \mathrm{~cm})$ bulk density occurred in IT plots treaded at $>$ FC. Treading wet soil greatly increased (up to 8 times) the amount of $\mathrm{N}_{2} \mathrm{O}$ emitted. The highest cumulative $\mathrm{N}_{2} \mathrm{O}$ emissions were from IT ( $14.9 \mathrm{~kg} \mathrm{~N} / \mathrm{ha}$ ) and MT $(12.7 \mathrm{~kg} \mathrm{~N} / \mathrm{ha})$ urine-applied plots treaded at $>$ FC. There was no difference in $\mathrm{N}_{2} \mathrm{O}$ emitted from treaded $<\mathrm{FC}$ and untreaded plots ( 1.5 to $2.4 \mathrm{~kg} \mathrm{~N} / \mathrm{ha}$ ) where urine was applied. Where urine was not applied, $\mathrm{N}_{2} \mathrm{O}$ emissions were negligible $(0.2$ to $0.5 \mathrm{~kg} \mathrm{~N} / \mathrm{ha}$ ). Soil compaction reduced DM production (June to October) by up to $50 \%$ in IT and MT plots treaded at $>$ FC. Treading at FC also caused a significant loss of DM production in the IT plots but not in the MT plots. DM production in the NT plots was unaffected by treading. Establishing winter forage crops by direct drilling may be an important management option to mitigate $\mathrm{N}_{2} \mathrm{O}$ emissions and maintain high DM production of grazed forages, as will avoiding grazing when soils are wet.
\end{abstract}

Keywords: forage crops, grazing, nitrous oxide, soil compaction, tillage, urine

\section{Introduction}

The grazing of winter forage crops by dairy cows on wet soil can result in soil compaction that may limit crop regrowth. Compaction influences a range of soil physical properties, such as bulk density, soil porosity, and water holding capacity, that are important to maintaining plant growth and environmental quality (Lipiec \& Hatano
2003). The effects of pastoral grazing on soil physical condition and pasture performance have received some research attention (Drewry et al. 2001; Singleton \& Addison 1999). However, the effects of grazing winter forage crops on subsequent dry matter (DM) production are not well understood.

In pastoral systems, grazing by livestock can result in the production of large amounts of nitrous oxide $\left(\mathrm{N}_{2} \mathrm{O}\right)$, a potent greenhouse gas, because the high nitrogen $(\mathrm{N})$ concentrations in livestock urine stimulate rapid denitrification, especially when soil moisture contents are high (de Klein \& van Logtestijn 1994; Oenema et al. 1997). Water filled porosity has been identified as a key indicator of $\mathrm{N}_{2} \mathrm{O}$ emissions since moisture content will affect diffusion of oxygen through the soil matrix (Linn \& Doran 1984). In general, high $\mathrm{N}_{2} \mathrm{O}$ emissions from denitrification can occur in a wide range of intensive agricultural systems when water filled pore space (WFPS) exceeds $60 \%$ (Dobbie \& Smith 2003).

The effects of soil compaction on $\mathrm{N}_{2} \mathrm{O}$ emissions have been reported for some intensive agricultural systems (Ball et al. 1999b; Hansen et al. 1993; Ruser et al. 1998), and the effects of compaction from stock treading on $\mathrm{N}_{2} \mathrm{O}$ emissions suggest that compaction by stock treading could double emissions from pasture (Oenema et al. 1997). In New Zealand, soil compaction caused a threefold increase in $\mathrm{N}_{2} \mathrm{O}$ emissions from a urine amended dairy pasture (Bhandral et al. 2003).

One of the key differences between winter grazing of pasture and forage crops is the use of tillage to establish the latter. Tillage can significantly alter soil structure and thereby increase susceptibility to compaction, especially when soils are wet. While a number of studies have investigated the effects of tillage on soil $\mathrm{N}_{2} \mathrm{O}$ emissions, there is a need for information on how the interaction of tillage practices and compaction affects $\mathrm{N}_{2} \mathrm{O}$ emissions (Yamulki \& Jarvis 2002). Some studies have reported higher $\mathrm{N}_{2} \mathrm{O}$ emissions from no-tillage than conventional tillage soils (Ball et al. 1999b), as a result of increased soil moisture content, water conservation and lower soil gas diffusivity, whereas other studies report no significant effects of tillage on $\mathrm{N}_{2} \mathrm{O}$ emissions (Elmi et al. 2003; Yamulki \& Jarvis 2002).

To address some of these uncertainties we conducted a field trial to test the hypothesis that the use of no-tillage 
practices to establish forage crops out of pasture will reduce soil compaction, lower emissions of $\mathrm{N}_{2} \mathrm{O}$ and increase DM production following grazing as compared to conventional and minimum tillage systems.

\section{Materials and methods \\ Site and design}

The field trial was conducted from March to October 2003 at Lincoln, Canterbury. The soil at the site was a Wakanui silt loam classified as a mottled immature Pallic soil (Hewitt 1993). A grass/clover pasture (>15 years old) was sprayed with glyphosate prior to sowing (3 March) a multi-grazing Triticale crop (cv Doubletake). The seed bed was prepared with either (a) intensive (IT: plough to $20 \mathrm{~cm}$ depth, maxi-till, roll and harrow), (b) minimum (MT: disc to $10 \mathrm{~cm}$ depth, roll and harrow) or (c) no-tillage (NT) practices. These main plots were $9 \mathrm{x}$ $9 \mathrm{~m}$ in size, replicated three times. Production of DM was estimated from sub-samples cut from each plots in June, after which the site was mowed to $10 \mathrm{~cm}$ height. Six split-plots ( $3 \mathrm{~m} \times 1 \mathrm{~m})$ were then established within each main tillage plot to determine the effects of soil moisture during grazing, animal treading and urine on soil compaction, $\mathrm{N}_{2} \mathrm{O}$ emissions and plant performance (Table 1). A buffer strip of at least $1 \mathrm{~m}$ surrounded each split plot.

Table 1 Split plot treatments imposed at simulated grazing.

\begin{tabular}{cccc}
\hline $\begin{array}{c}\text { Split plot } \\
\text { treatment }\end{array}$ & $\begin{array}{c}\text { Soil moisture } \\
\text { content }\end{array}$ & Treading & $\begin{array}{c}\text { Urine } \\
\text { application }\end{array}$ \\
\hline 1 & $<$ FC $^{\text {a }}$ & Yes & Yes \\
2 & FC & Yes & Yes \\
3 & $>$ FC & Yes & Yes \\
4 & FC & Yes & No \\
5 & FC & No & Yes \\
6 & FC & No & No \\
\hline
\end{tabular}

${ }^{a} \mathrm{FC}$ (field capacity) $=35 \% \mathrm{v} / \mathrm{v} ;<\mathrm{FC}=27 \% ;>\mathrm{FC}=40 \%$.

\section{Simulated grazing}

Soil moisture contents for subplots at or above FC (Table 1) were adjusted by applying spray irrigation immediately before grazing. Soil moisture contents $<$ FC (Split plot Treatment 1, Table 1) were achieved by covering subplots with cloche frames during rainfall events from mid-May until simulated grazing. A single grazing event was simulated in June 2003 by using a mechanical cow hoof that applied a pressure of $220 \mathrm{kPa}$ to the soil surface, representing the treading impact of an adult Friesian cow (Di et al. 2001). In addition, synthetic urine (Clough et al. 1998) was uniformly applied by hand at a rate of 800 $\mathrm{kg} \mathrm{N} / \mathrm{ha}$. Dry matter production following grazing was calculated by the difference in triticale DM remaining at the time of simulated grazing and DM estimates from sub-samples cut from each subplot at the end of the study.

\section{$\mathrm{N}_{2} \mathrm{O}$ measurements}

$\mathrm{N}_{2} \mathrm{O}$ fluxes were determined using a closed chamber technique (Hutchinson \& Mosier 1981). Chambers (10 $\mathrm{cm}$ depth) were made from $25 \mathrm{~cm}$ diameter PVC pipe with welded lids. Bases (15 cm depth), made from the same diameter PVC pipe, were inserted into the soil (5 $\mathrm{cm}$ depth) to enable gas fluxes to be measured at the same position within each plot. A water-filled channel at the top of each base produced a gas tight seal with the chamber during measurements. Within each subplot, $\mathrm{N}_{2} \mathrm{O}$ concentrations were measured in the chamber headspace at three time intervals $(0,20$ and 40 minutes) after chamber closure. Chamber heights were extended during the trial to accommodate the growing triticale. Gas samples were analysed using a gas chromatograph (GC-17A, Shimadzu Corporation, Kyoto) fitted with a ${ }^{63} \mathrm{Ni}$-Electron capture detector. Measurements were made on 27 occasions over 92 days.

\section{Soil measurements}

Soil bulk density was measured at 4 depths $(0$ to $7.5 \mathrm{~cm}$, 7.5 to $15 \mathrm{~cm}, 15$ to $25 \mathrm{~cm}$ and 25 to $30 \mathrm{~cm}$ ) within 3 weeks of the simulated grazing. On eight occasions during the period of gas sampling, soil mineral $\mathrm{N}$ was extracted from soil samples $(0-25 \mathrm{~cm}$ depth) using potassium chloride and analysed using a Rapid Flow Analyser (Astoria-Pacific Inc., Clackamas, Oregon). Soil moisture $(0-10 \mathrm{~cm})$ was measured hourly in each plot using $\mathrm{ECH}_{2} \mathrm{O}$ capacitance probes (Decagon Devices Inc., Pullman, Washington) connected to a datalogger and multiplexers (Campbell Scientific Inc., North Logan, Utah). Soil moisture, bulk density and particle density measurements were used to calculate water filled pore space (WFPS). Rainfall, air temperature and soil temperature were also measured at the site.

\section{Statistical analyses}

The effects of tillage, treading, soil moisture content at treading and urine on dry matter production following grazing were analysed using split-plot analysis of variance. Contrasts between the various split plots were included in the analysis of variance. Treatment effects on bulk density were analysed using split-split plot analysis of variance. A mixed model fitted using REML (Residual Maximum Likelihood) analysis tested for the effects of tillage, treading, soil moisture content at treading and urine on $\mathrm{N}_{2} \mathrm{O}$ emissions, WFPS and mineral $\mathrm{N}$ with time. The $\mathrm{N}_{2} \mathrm{O}$ flux data required $\log$ transformation to make variance more homogeneous; the results presented have been back transformed. $\mathrm{N}_{2} \mathrm{O}$ flux comparison between tillage means is made using the least significant 
Figure 1 Soil bulk density $(n=3)$ of treaded plots at three moisture contents $(<F C, F C$ and $>F C)$ and untreaded plots at FC (hatched bar) following IT, MT and NT. The error bar represents the LSD $(P<0.05)$ for comparisons of the tillage and moisture treatments that were grazed.

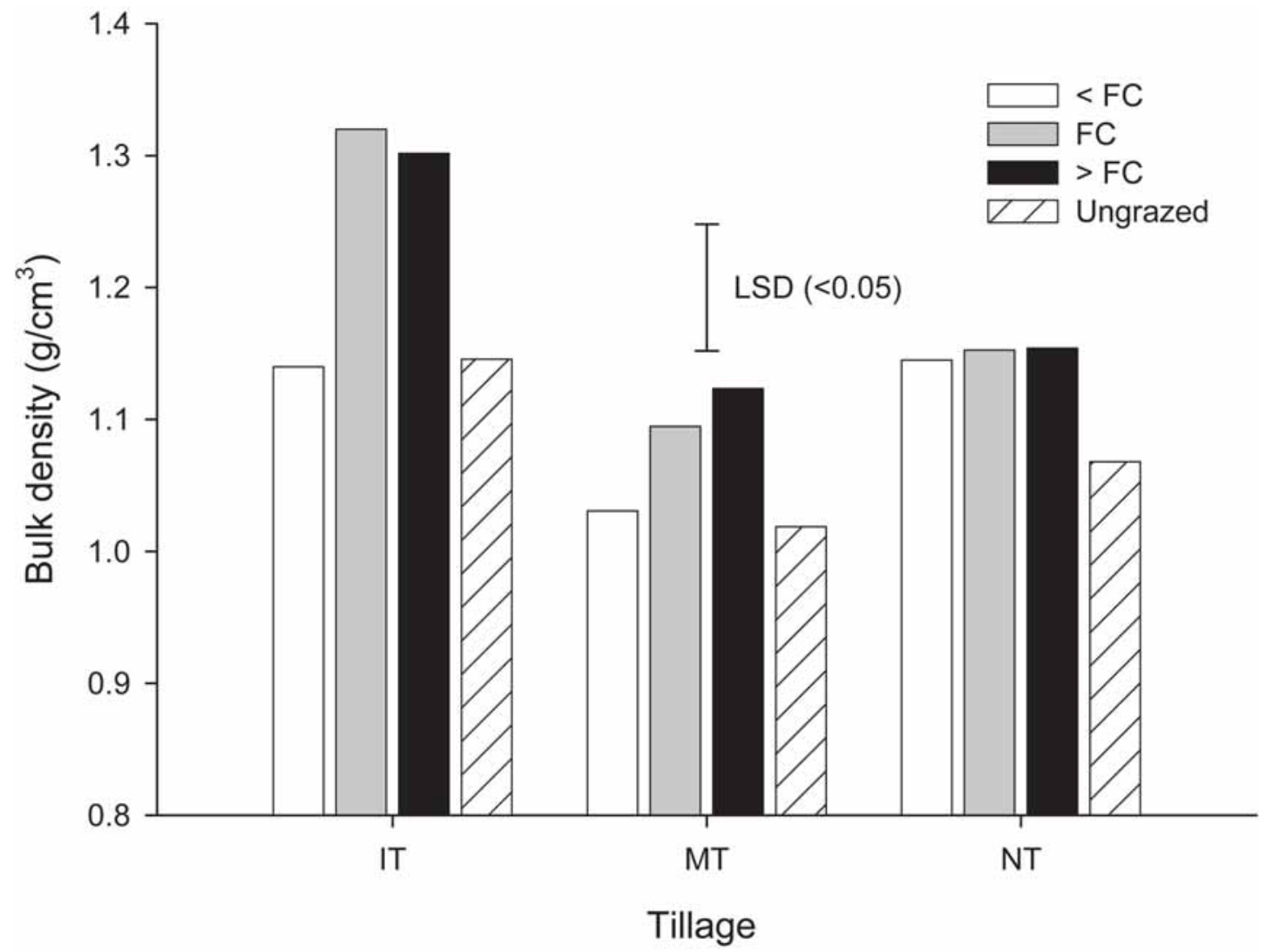

ratio (LSR). The LSR is the smallest ratio between two back-transformed means (largest mean/smallest mean) such that the larger mean is significantly greater than the smallest mean. For all the statistical analyses a significance level of $5 \%$ was used to test for treatment effects. Analyses were performed using the GenStat (version 7) software package.

\section{Results and discussion \\ Bulk density}

Prior to treading in June, soil bulk density and WFPS were similar at $0-7.5 \mathrm{~cm}$ depth (about $1.1-1.2 \mathrm{~g} / \mathrm{cm}^{3}$ ) for all three tillage systems. At $7.5-25 \mathrm{~cm}$ depth, however, bulk density and WFPS were lower under IT than MT or NT. Treading at field capacity increased surface soil bulk density $(0$ to $7.5 \mathrm{~cm})$ in all tillage treatments, the greatest increase occurring under IT (Figure 1). Treading at moisture contents above field capacity $(>\mathrm{FC})$ greatly increased the bulk density and WFPS of surface $(0-7.5 \mathrm{~cm})$ soil from IT plots (Figure 1). There was less compaction of surface soil when treading occurred below field capacity $(<\mathrm{FC})$, and bulk density values were similar to the plots that had no treading.

\section{Soil mineral $\mathrm{N}$ levels and $\mathrm{N}_{2} \mathrm{O}$ emissions}

Throughout the trial, soil mineral $\mathrm{N}$ contents at $0-25 \mathrm{~cm}$ depth remained above $50 \mathrm{~kg} \mathrm{~N} /$ ha in all plots (Figure 2). The application of urine in June resulted in a rapid increase in soil mineral $\mathrm{N}$ contents to $400 \mathrm{~kg} \mathrm{~N} / \mathrm{ha}$, which then decreased steadily during the remaining 10 weeks of the trial. Tillage, soil moisture and compaction treatments had little effect on soil mineral $\mathrm{N}$ contents.

There were significant effects of treading, moisture content at treading and urine $(\mathrm{P}<0.001)$ and tillage method on $\mathrm{N}_{2} \mathrm{O}$ emissions $(\mathrm{P}<0.05)$. Overall, the greatest cumulative $\mathrm{N}_{2} \mathrm{O}$ emission was from the IT soil and lowest from the NT soil (Table 2). The highest hourly fluxes of $\mathrm{N}_{2} \mathrm{O}$ were associated with high soil moisture and WFPS (Figure 2), following rainfall events, suggesting that the $\mathrm{N}_{2} \mathrm{O}$ emissions are largely due to denitrification, as reported in other studies (de Klein \& van Logtestijn 1996; Linn \& Doran 1984). The highest mean $\mathrm{N}_{2} \mathrm{O}$ fluxes and greatest cumulative $\mathrm{N}_{2} \mathrm{O}$ emissions were from intensively tilled plots, compacted at moisture 
Figure 2 Mean $\mathrm{N}_{2} \mathrm{O}$ flux, WFPS $(0-7.5 \mathrm{~cm})$ and rainfall, and mineral $\mathrm{N}(0-25 \mathrm{~cm}$ depth) after being compacted when soil was above field capacity and urine had been applied to plots $(n=3)$ growing triticale following three tillage methods. $\mathrm{N}_{2} \mathrm{O}$ and mineral $\mathrm{N}$ data are back-transformed from log-transformed data.

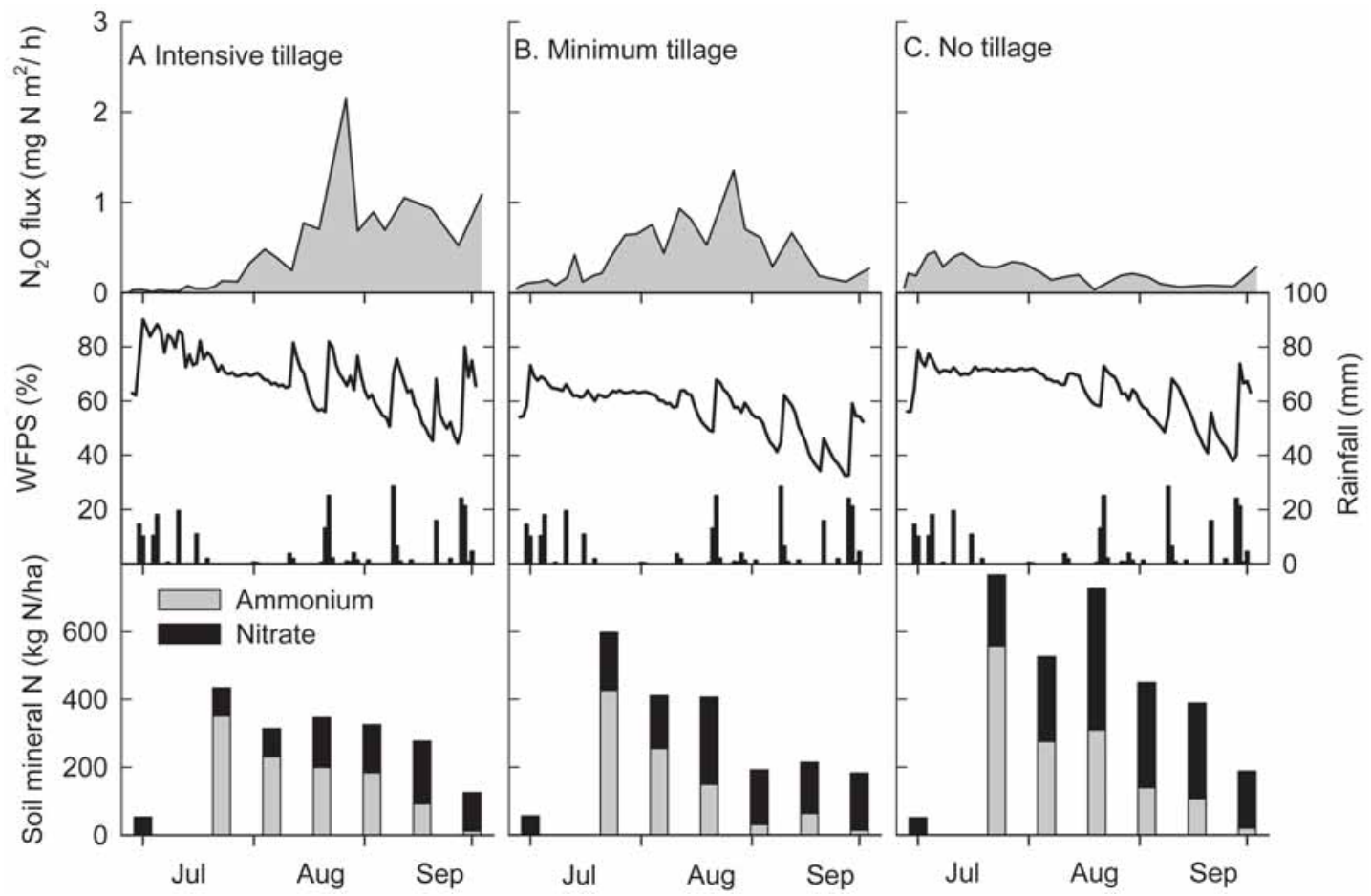

Table 2 Cumulative $\mathrm{N}_{2} \mathrm{O}$ emissions for a 90 day period following grazing of intensive, minimum or no tillage triticale plots. Data are means of three replicates.

\begin{tabular}{|c|c|c|c|c|c|}
\hline \multicolumn{3}{|c|}{ Split plot treatments } & \multirow{2}{*}{\multicolumn{3}{|c|}{$\begin{array}{l}\text { Main plot } \\
\text { Cumulative } \mathrm{N}_{\mathrm{O}} \mathrm{O} \text { flux }(\mathrm{kg} \mathrm{N} / \mathrm{ha})\end{array}$}} \\
\hline \multirow{2}{*}{$\begin{array}{l}\text { Moisture } \\
\text { content }\end{array}$} & \multirow[t]{2}{*}{ Treading } & \multirow{2}{*}{$\begin{array}{l}\text { Urine } \\
\text { added }\end{array}$} & & & \\
\hline & & & IT & $\mathrm{MT}$ & NT \\
\hline$<\mathrm{FC}$ & Yes & Yes & 1.45 & 1.87 & 2.04 \\
\hline$>\mathrm{FC}$ & Yes & Yes & 14.86 & 12.68 & 4.97 \\
\hline $\mathrm{FC}$ & Yes & Yes & 5.73 & 3.18 & 3.0 \\
\hline $\mathrm{FC}$ & No & Yes & 2.36 & 1.66 & 2.07 \\
\hline $\mathrm{FC}$ & Yes & No & 0.31 & 0.53 & 0.37 \\
\hline $\mathrm{FC}$ & No & No & 0.24 & 0.28 & 0.46 \\
\hline
\end{tabular}

For comparisons between different tillage treatments LSR $(P<0.05)=2.09$ (d.f. $=26)$.

For comparisons within tillage treatments, $\operatorname{LSR}(P<0.05)=1.97($ d.f. $=30)$.

The LSR is the smallest ratio between two back-transformed means (largest mean/smallest mean) such that the larger mean is significantly greater than the smallest mean.

contents $>$ FC (Figure 2, Table 2). The highest mean $\mathrm{N}_{2} \mathrm{O}$ fluxes from the IT and MT plots that had been treaded at $>\mathrm{FC}$ and had urine applied were higher than from plots that had urine $(655 \mathrm{~kg} \mathrm{~N} / \mathrm{ha})$ applied to untreaded pasture on a moderately drained silt loam in Canterbury $\left(0.7 \mathrm{mg} \mathrm{N} / \mathrm{m}^{2} / \mathrm{h}\right)$, but are lower than those from urine-applied (592 $\mathrm{kg} \mathrm{N} / \mathrm{ha})$, untreaded pasture on a poorly drained silt loam in Otago $\left(4.9 \mathrm{mg} \mathrm{N} / \mathrm{m}^{2} / \mathrm{h}\right)(\mathrm{de}$ Klein et al. 2003).

$\mathrm{N}_{2} \mathrm{O}$ emissions from compacted soils were up to eight times greater than those of untreaded soil (Table 2). Increased $\mathrm{N}_{2} \mathrm{O}$ production due to soil compaction has been observed in several pastoral land-use and other intensive agricultural systems (e.g. Ball et al. 1999b; 
Figure 3 Mean DM production of Doubletake triticale between June and October following simulated grazing at 3 moisture contents ( $<$ FC, FC and $>$ FC) established by IT, MT or NT $(n=3)$. The error bar represents the LSD $(P<0.05)$ for comparison of tillage and moisture treatments.

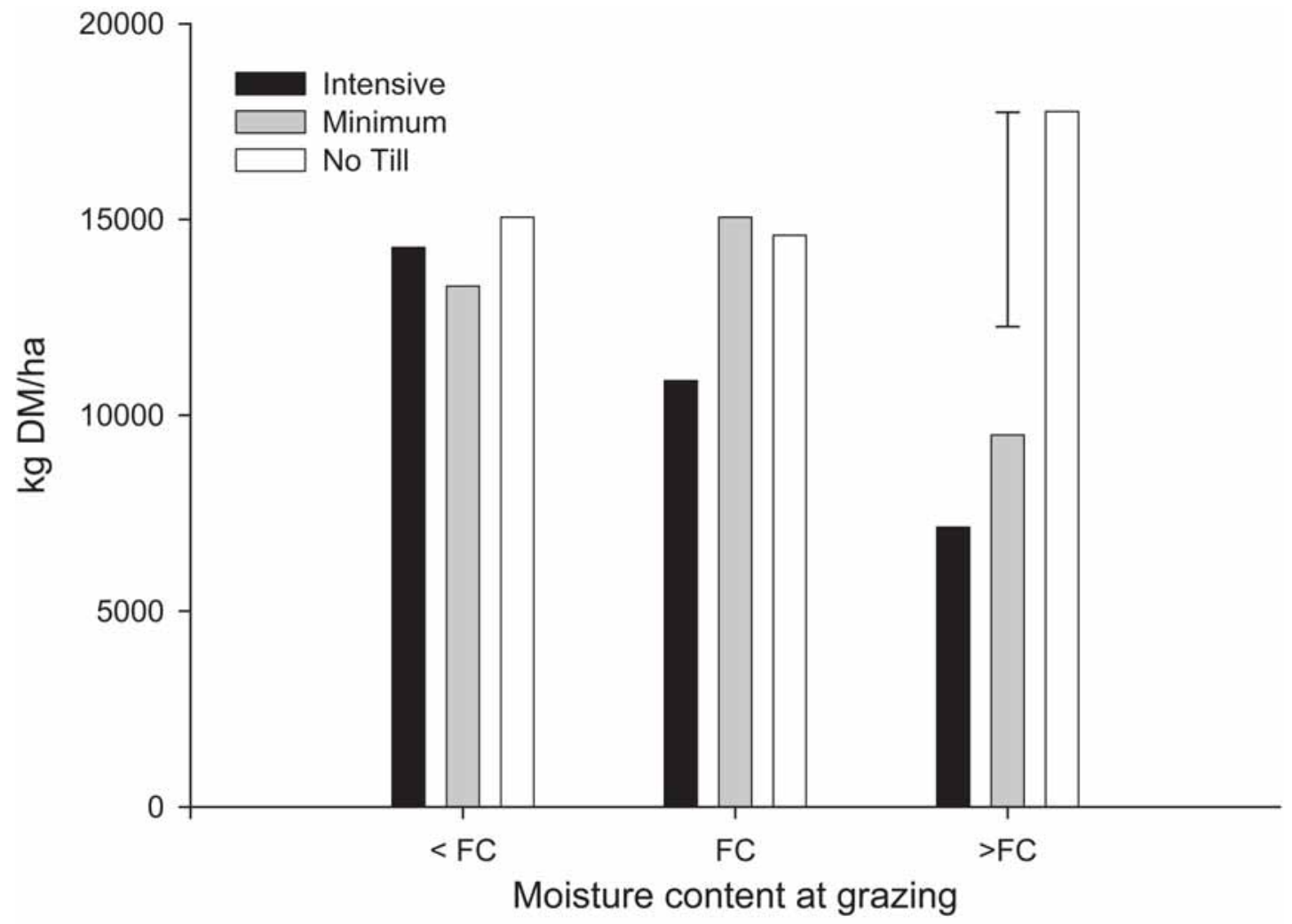

Ruser et al. 1998; Yamulki \& Jarvis 2002). Bhandral et al. (2003) measured a three-fold increase in cumulative $\mathrm{N}_{2} \mathrm{O}$ emissions between tractor-compacted $(9.2 \mathrm{~kg} \mathrm{~N} /$ ha) and uncompacted $(2.9 \mathrm{~kg} \mathrm{~N} / \mathrm{ha})$ urine amended pasture plots on a Manawatu fine sandy loam soil. In contrast to a number of other studies, we found no significant difference in $\mathrm{N}_{2} \mathrm{O}$ emissions between the NT and IT plots that had not been compacted (Table 2). These $\mathrm{N}_{2} \mathrm{O}$ emissions were small compared to those from plots that had been compacted when the soil was at or above FC (Table 2).

WFPS and mineral $\mathrm{N}$ contents were not good predictors of the amount of $\mathrm{N}_{2} \mathrm{O}$ emitted as has been shown elsewhere (Ball et al. 1999b; Yamulki \& Jarvis 2002). From their study of short-term effects of tillage and compaction, Yamulki \& Jarvis (2002) suggested that other factors affecting the production, transport and residence time of $\mathrm{N}_{2} \mathrm{O}$ were responsible for differences in $\mathrm{N}_{2} \mathrm{O}$ emissions. The key soil properties affected by compaction that may influence the production and transport of $\mathrm{N}_{2} \mathrm{O}$ and rate of oxygen diffusion through the soil matrix include macroporosity, soil pore tortuosity and water holding capacity (Ball et al. 1999a).
Urine application had a strong effect on $\mathrm{N}_{2} \mathrm{O}$ emissions in this study. Where urine was not applied, cumulative $\mathrm{N}_{2} \mathrm{O}$ emissions were very low (Table 2). In contrast, where urine was applied, $\mathrm{N}_{2} \mathrm{O}$ emissions were low during the first month following urine application, as soil mineral $\mathrm{N}$ contents were also low during this time, but tended to be higher from August onwards, by which time much of the applied urine had been converted to nitrate (Figure 2). From mid-July onwards, emission peaks were recorded following most rainfall events (Figure 2) and corresponded with an increase in the WFPS of the soil.

\section{Effects on DM production}

Dry matter production before grazing in June was unaffected by tillage treatment $(2400 \mathrm{~kg} \mathrm{DM} / \mathrm{ha})$. Treading, moisture content at treading and urine application affected the triticale DM production (Figure $3, \mathrm{P}<0.05)$. There was also some evidence to suggest that tillage method was also important $(\mathrm{P}=0.06$ for tillage $\mathrm{x}$ split plots interaction effect). As the soil moisture content at treading increased from $<\mathrm{FC}$ to $>\mathrm{FC}, \mathrm{DM}$ production decreased two fold (Figure 3). In contrast, DM production on the NT plots was unaffected by soil 
moisture content at grazing. The application of urine increased triticale re-growth by up to $50 \%$, this effect being greatest in the NT plots.

\section{Conclusions}

The use of no-tillage practices to establish a multi-grazing winter forage crop (ex-pasture) had significant benefits over other tillage practices in terms of environmental impacts and forage crop performance. Soil compaction, due to grazing under wet conditions, increased $\mathrm{N}_{2} \mathrm{O}$ production and decreased forage crop production. Conventional tillage practices (IT) for establishing winter forage are more likely to result in soil compaction than reduced tillage systems. Hence where these winter forages are grazed, establishment by direct drilling is likely to be an important option for mitigating $\mathrm{N}_{2} \mathrm{O}$ emissions, while maintaining high DM yields. Restricting grazing when soils are wet will reduce the risk of increasing $\mathrm{N}_{2} \mathrm{O}$ emissions and loss of DM production.

\section{ACKNOWLEDGEMENTS}

This study was funded by the Foundation for Research Science \& Technology under contracts C02X0218 and C02X0304. We wish to thank Lincoln University for the use of their mechanical hoof. Ruth Butler and Duncan Hedderley provided statistical advice.

\section{REFERENCES}

Ball, B.C.; Parker, J.P.; Scott, A. 1999a. Soil and residue management effects on cropping conditions and nitrous oxide fluxes under controlled traffic in Scotland 2. Nitrous oxide, soil N status and weather. Soil \& Tillage Research 52: 191-201.

Ball, B.C.; Scott, A.; Parker, J.P. 1999b. Field $\mathrm{N}_{2} \mathrm{O}$, $\mathrm{CO}_{2}$ and $\mathrm{CH}_{4}$ fluxes in relation to tillage, compaction and soil quality in Scotland. Soil \& Tillage Research 53: 29-39.

Bhandral, R.; Saggar, S.; Bolan, N.S.; Hedley, M.J. 2003. Nitrous oxide fluxes in soil as influenced by compaction. Proceedings of the New Zealand Grassland Association 65: 265-271.

Clough, T.J.; Ledgard, S.F.; Sprosen, M.S.; Kear, M.J. 1998. Fate of ${ }^{15} \mathrm{~N}$ labelled urine on four soil types. Plant and Soil 199: 195-203.

de Klein, C.A.M.; van Logtestijn, R.S.P. 1994. Denitrification and $\mathrm{N}_{2} \mathrm{O}$ emission from urine-affected grassland soil. Plant and Soil 163: 235-241.

de Klein, C.A.M.; van Logtestijn, R.S.P. 1996. Denitrification in grassland soils in the Netherlands in relation to irrigation, $\mathrm{N}$-application rate, soil water content and soil temperature. Soil Biology and Biochemistry 28: 231-237.

de Klein, C.A.M.; Barton, L.; Sherlock, R.R.; Li, Z.; Littlejohn, R.P. 2003. Estimating a nitrous oxide emission factor for animal urine from some New Zealand pastoral soils. Australian Journal of Soil Research 41: 381-399.

Di, H.; Cameron, K.C.; Milne, J.; Drewery, J.J.; Smith, N.P.; Hendry, T.; Moore, S.; Reijnen, B. 2001. A mechanical hoof for simulating animal treading under controlled conditions. New Zealand Journal of Agricultural Research 44: 111-116.

Dobbie, K.E.; Smith, K.A. 2003. Nitrous oxide emission factors for agricultural soils in Great Britain: the impact of soil water-filled pore space and other controlling variables. Global Change Biology 9: 204-218.

Drewry, J.J.; Cameron, K.C.; Buchan, G.D. 2001. Effect of simulated dairy cow treading on soil physical properties and ryegrass pasture yield. New Zealand Journal of Agricultural Research 44: 181-190.

Elmi, A.A.; Madramootoo, C.; Hamel, C.; Liu, A. 2003. Denitrification and nitrous oxide to nitrous oxide plus dinitrogen ratios in the soil profile under three tillage systems. Biology and Fertility of Soils 38: 340-348.

Hansen, S.; Maehlum, J.E.; Bakken, L.R. 1993. $\mathrm{N}_{2} \mathrm{O}$ and $\mathrm{CH}_{4}$ fluxes in soil influenced by fertilization and tractor traffic. Soil Biology and Biochemistry 25: 621630.

Hewitt, A.E. 1993. New Zealand Soil Classification. Manaaki Whenua-Landcare Research,Lincoln. 133 pp.

Hutchinson, G.L.; Mosier, A.R. 1981. Improved soil cover method for field measurement of nitrous oxide fluxes. Soil Science Society of America Journal 45: 311-316.

Linn, D.M.; Doran, J.W. 1984. Effect of water-filled pore space on carbon dioxide and nitrous oxide production in tilled and non-tilled soils. Soil Science Society of America Journal 48: 1267-1272.

Lipiec, J.; Hatano, R. 2003. Quantification of compaction effects on soil physical properties and crop growth. Geoderma 116: 107-136.

Oenema, O.; Velthof, G.L.; Yamulki, S.; Jarvis, S.C. 1997. Nitrous oxide emissions from grazed grassland. Soil Use and Management 13: 288-295.

Ruser, R.; Flessa, H.; Schilling, R.; Steindl, H.; Beese, F. 1998. Soil compaction and fertilization effects on nitrous oxide and methane fluxes in potato fields. Soil Science Society of America Journal 62: 1587-1595.

Singleton, P.L.; Addison, B. 1999. Effects of cattle treading on physical properties of three soils used for dairy farming in the Waikato, North Island, New Zealand. Australian Journal of Soil Research 37: 891-902.

Yamulki, S.; Jarvis, S.C. 2002. Short-term effects of tillage and compaction on nitrous oxide, nitric oxide, nitrogen dioxide, methane and carbon dioxide fluxes from grassland. Biology and Fertility of Soils 36: 224231. 